2 Clarke DN, Jones PF, Needham CD. Outcome in colorectal carcinoma: seven year study of a population. $B M \mathcal{F} 1980 ; 280: 431-5$.

3 Dukes CE. The classification of carcinoma of the rectum. I Path Bact 1932;35:323-32.

4 Registrar General Scotland. Annual report 1982. Edinburgh: HMSO, 1983. 5 Beart RW, Melton J, Maruta M, Dockerty MB, Frydenburg HB, O'Fallon WM. Trends in right and left colon cancer. Dis Colon Rectum 1983;26:393-8. 6 Kee F, Wilson RH, Gilliland R, Sloan JM, Rowlands BJ, Moorehead RJ. Changing site distribution of colorectal cancer. $B M \mathcal{F}$ 1992;305:158.

7 Brown SCW, Walsh S, Sykes PA. Operative mortality rate and surgery for colorectal cancer. $\mathrm{Br}$ f Surg 1988;75:645-7.

8 McArdle CS, Hole D, Hansell D, Blumgart LH, Wood CB. Prospective study of colorectal cancer in the West of Scotland: 10-year follow-up. Br f Surg 1990;77:280-2.

9 Finlay IG, Meek D, Brunton F, McArdle CS. Growth rate of hepatic metastases in colorectal carcinoma. Brf Surg 1988;75:641-4.

10 Hardcaste JD, Thomas WM. Chamberlain J Pye G, Sheffield J, James PD, 作 et al. Randomised controlled trial of faecal occult blood screening for
colorectal cancer. Lancet 1989;ii:1160-4.

11 Finlay IG, McArdle CS. Occult hepatic metastases in colorectal carcinoma. Brf Surg 1986;73:732-5.

12 Gray R, James R, Mossman J, Stenning S. AXIS-a suitable case for treatment. Brf Cancer 1991;63:841-5.

13 Taylor I, Machin D, Mullee M, Trotter G, Cooke T, West C. A randomised controlled trial of adjuvant portal vein cytotoxic perfusion in colorectal cancer. Br 7 Surg 1985;72:359-63.

14 Fieldig LP, Hitinger $R$, Grace RH, Fry JS. Rin colorectal adenocarcinoma. Lancet 1992;340:502-6.

15 Archer SG, Gray BN. Vascularisation of small liver metastases. $\mathrm{Br} f$ Surg 1989;76:545-8.

16 Moertel CG, Fleming TR, Macdonald HS, Haller DG, Laurie JA, Goodman PJ, et al. Levamisole and fluorouracil for adjuvant therapy of resected colon carcinoma. N Engl F Med 1990;322:352-8.

17 Fielding LP. Mesorectal excision for rectal cancer. Lancet 1993;341:471-2. 18 Collins REC. The organisation of general surgery services in a population. Ann $R$ Coll Surg Engl 1993;75:\$33-4. (College and faculty bulletin supplement.)

19 Callaghan J. Colorectal cancer in a small rural hospital. Am f Surg 1990;159: $277-81$.

20 Jackson BT. Coloproctology-a specialty in transition. Ann R Coll Surg Engl 1992;74:S63-6. (College and faculty bulletin supplement.)

1992;74:S63-6. (College and faculty bulletin supplement.) 21 Darby CR, Berry AR, Mortensen N. Managem

22 Association of Surgeons of Great Britain and Ireland. The organisation of general 22 Association of Surgeons of Great Britain and
surgical services. London: The Association, 1993.

(Accepred 13 fuly 1993)
School of Public Health

Free University of

Brussels, Brussels,

Belgium

M Dramaix, biostatistician

CUMUBAC Medical

Team, Free University of

Brussels, Brussels,

Belgium

P Hennart, director

$\mathrm{R}$ Tonglet, project manager

$\mathrm{Ph}$ Donnen, project manager

$\mathrm{R}$ Smets, paediatrician

Queen Fabiola Children's Hospital, Free University of Brussels, Brussels, Belgium

D Brasseur, paediatric

nutritionist

Natural Sciences Research

Centre, Lwiro, Zaire

P Bahewere, general

practitioner

O Mudjene, general

practitioner

Correspondence to:

Dr P Hennart, Laboratory of Epidemiology and Social Medicine, School of Public Health, (ULB), Route de Lennix, 808 B-1070

Brussels, Belgium.

\title{
Serum albumin concentration, arm circumference, and oedema and subsequent risk of dying in children in central Africa
}

\author{
MDramaix, P Hennart, D Brasseur, $\mathrm{P}$ Bahwere, $\mathrm{O}$ Mudjene, $\mathrm{R}$ Tonglet, Ph|Donnen, R Smets
}

\section{Abstract}

Objective-To measure the prognostic value of clinical, anthropometric, and biological indicators of protein energy malnutrition in hospitalised children.

Design-Hospital based follow up study from admission to discharge or death of a cohort of children.

Setting-Paediatric hospital in Zaire.

Subjects-1129 children consecutively admitted between August 1986 and October 1988.

Main outcome measures-Height, weight, arm circumference, skinfold thicknesses, serum albumin concentration, and mortality.

Results-Mortality was higher in wasted children and in those with a mid-upper arm circumference $<125 \mathrm{~mm}$, a serum albumin concentration $<16 \mathrm{~g} /$, and oedema. After multivariate analysis, serum albumin concentration was the best predictor of subsequent risk of dying. Mid-upper arm circumference and oedema, however, still contributed considerably to evaluation of mortality.

Conclusions-In this specific environment of central Africa an isolated clinical sign such as oedema is not enough to detect children with a high risk of dying among those admitted to paediatric wards with severe protein energy malnutrition. Measurement of additional indicators such as arm circumference and serum albumin concentration seems to be of crucial importance.

\section{Introduction}

In developing countries protein energy malnutrition is common among children admitted to hospital and is associated with a high morbidity and mortality. ${ }^{1-4} \mathrm{~A}$ nutritional assessment is mandatory to treat and follow these severely ill patients. Different anthropometric and biological variables have been proposed, biometry being the most commonly used tool. Major signs looked for are oedema and muscle wastage, isolated or in combination.

Most common classifications of protein energy malnutrition are usually based on weight loss compared with international reference data and the presence of oedema, which enables differentiation of kwashiorkor from marasmus. ${ }^{5}$ Different authors have found a close association between some anthropometric measurements and the risk of dying during the hospital stay. ${ }^{6-7}$ In the oedematous form of protein energy malnutrition, however, there is no simple association between mortality and the severity of weight loss, whereas the albumin concentration at admission is strongly associated with mortality. ${ }^{8}$

In central Africa all forms of protein energy malnutrition are often encountered, particularly in hospitals. Our aim was to detect from various anthropometric measurements, clinical signs, and biochemical indices very commonly performed or collected those mainly associated from the time of admission with a higher risk of dying.

Our purpose was to identify the most discriminant and predictive of these markers.

\section{Patients and methods}

The children's hospital of Lwiro is located in south Kivu in Zaire, at the eastern border of the country. In these highlands most people are living by subsistence farming, and their food supply is low in energy and protein with large seasonal variations.

Between August 1986 and October 19881129 children admitted consecutively to the paediatric hospital of Lwiro were included in the follow up study; two thirds of the children suffered from clinical protein energy malnutrition.

We analysed different variables at baseline and their association with subsequent mortality. The median age of the children was 27 months; three quarters were aged under 5 years and nearly half under 2 years. The average duration of admission to hospital was 26 days, but nearly half of the children had left the hospital within two weeks. At the time of admission 395 children suffered from gastroenteritis and 203 were dehydrated; moreover 350 had a body temperature above $37.5^{\circ} \mathrm{C}, 237$ had an infection of the lower respiratory tract, and 304 had malaria.

We studied the anthropometric indicators of height for age, weight for height, mid-upper arm circumference, and tricipital and subscapular skinfold thicknesses. Weight was measured to the nearest $10 \mathrm{~g}$. Weight scales were calibrated daily. Recumbent length 
or standing height were measured to the nearest $1 \mathrm{~mm}$ and $2 \mathrm{~mm}$, respectively. Arm circumference was measured with a plastic tape to the nearest millimetre. Skinfold thicknesses were measured in the upright position with Harpenden callipers. According to the Waterlow classification children were classified in four groups of height and weight. ${ }^{90}$ They were classified for arm circumference according to cut off points of $<115 \mathrm{~mm}, 115-124 \mathrm{~mm}, 125-134 \mathrm{~mm}$, and $\geqslant 135 \mathrm{~mm}$. Children were also classified according to the quarters of the distribution of tricipital and subscapular skinfold thicknesses.

In addition, we considered in the analyses the presence of oedema and serum albumin concentration. The presence of oedema was determined by applying pressure for $30 \mathrm{~s}$ to the pretibial region. Serum albumin concentration was determined according to the technique of Sonnet and Rodhain. ${ }^{11}$ For subsequent analyses serum albumin concentrations were categorised into four groups ( $<16 \mathrm{~g} / \mathrm{l}, 16-22 \mathrm{~g} / 1,23-29 \mathrm{~g} / \mathrm{l}$, and $\geqslant 30 \mathrm{~g} / \mathrm{l}$ ).

As we aimed to establish early detection of accurate predictors of mortality all data collected at baseline were considered, notwithstanding the presence or absence of oedema or a possible degree of dehydration. Continuous variables were categorised to obtain estimates of their effects on mortality that are easy to interpret; for arm circumference and serum albumin concentration usual cut off points were used.

Statistical analysis was performed by using the SPSS 4.0 release for Unix and the biomedical programs data package. ${ }^{12}{ }^{13}$ Survival at 60 days was the end point considered; cumulative mortality (proportion of deaths at 60 days) was obtained in each category of indicators. To measure the strength of the association between these indicators and subsequent risk of dying we computed relative risks and their $95 \%$ confidence intervals. The $\chi^{2}$ test was used in the analysis of contingency tables. Finally, logistic regression was applied by using a backward elimination procedure. Because data were missing in 174 subjects on admission, the sample on which logistic regression could be applied was reduced from 1129 to 955 subjects. Age, categorised into four groups ( $<12$ months, 12-23

TABLE I-Distribution of subjects, cumulative mortality at 60 days, and relative risk (95\% confidence interval) in each category of anthropometric variables, serum albumin concentration, oedema, and age for the children admitted to hospital in Lwiro between August 1986 and October 1988

\begin{tabular}{|c|c|c|c|}
\hline Variable & $\begin{array}{l}\text { Distribution } \\
(\text { No }(\%))\end{array}$ & $\begin{array}{c}\text { Cumulative mortality } \\
(\text { No }(\%))\end{array}$ & $\begin{array}{c}\text { Relative } \\
\text { risk } \\
\text { (95\% confidence } \\
\text { interval) }\end{array}$ \\
\hline \multicolumn{4}{|c|}{ Waterlow classification $(n=959)$} \\
\hline Wasted and stunted & $180(18 \cdot 8)$ & $50(27 \cdot 8)$ & $4.3(2 \cdot 6$ to $7 \cdot 0)$ \\
\hline Stunted & $400(41 \cdot 7)$ & $60(15 \cdot 0)$ & $2.3(1.4$ to 3.8$)$ \\
\hline Wasted & $87(9 \cdot 1)$ & $14(16 \cdot 1)$ & $2.5(1.3$ to 4.7$)$ \\
\hline Normal & $292(30 \cdot 4)$ & $19(6.5)$ & 1.0 \\
\hline \multicolumn{4}{|c|}{ Arm circumference $(\mathrm{mm})(\mathrm{n}=1043)$ : } \\
\hline$<115$ & $175(16 \cdot 8)$ & $57(32 \cdot 6)$ & $3.7(2.6$ to 5.3$)$ \\
\hline $115-124$ & $159(15 \cdot 2)$ & $33(20 \cdot 8)$ & $2.4(1.6$ to 3.6$)$ \\
\hline $125-134$ & $211(20 \cdot 2)$ & $28(13.3)$ & $1.5(0.9$ to 2.4$)$ \\
\hline$\geqslant 135$ & $498(47 \cdot 8)$ & $44(8 \cdot 8)$ & 1.0 \\
\hline \multicolumn{4}{|c|}{ Triceps skinfold thickness $(\mathrm{mm})(\mathrm{n}=1041)$ : } \\
\hline$\leqslant 5$ & $256(24 \cdot 6)$ & $51(19.9)$ & $2.0(1.3$ to 3.0$)$ \\
\hline 6-7 & $352(33.8)$ & $58(16.5)$ & $1.6(1.1$ to 2.5$)$ \\
\hline 8 & $158(15 \cdot 2)$ & $24(15 \cdot 2)$ & $1.5(0.9$ to 2.5$)$ \\
\hline$\geqslant 9$ & $275(26.4)$ & $28(10 \cdot 2)$ & $1 \cdot 0$ \\
\hline \multicolumn{4}{|c|}{ Subscapular skinfold thickness $(\mathrm{mm})(\mathrm{n}=1041)$ : } \\
\hline$\leqslant 3$ & $196(18 \cdot 8)$ & $62(31 \cdot 6)$ & $4.5(2.9$ to 6.9$)$ \\
\hline $\begin{array}{l}4 \\
5\end{array}$ & $\begin{array}{l}247(23.7) \\
229(22.0)\end{array}$ & $\begin{array}{l}44(17 \cdot 8) \\
31(13 \cdot 5)\end{array}$ & $\begin{array}{l}2.5(1.6 \text { to } 4.0) \\
1.9(1.2 \text { to } 3.2)\end{array}$ \\
\hline$\stackrel{5}{2} \geqslant 6$ & $369(35.4)$ & $26(7 \cdot 0)$ & 1.0 \\
\hline \multicolumn{4}{|c|}{ Serum albumin $(g / 1)(n=1022)$ : } \\
\hline$<16$ & $214(20.9)$ & $87(40.7)$ & $10.6(5.5$ to 20.5$)$ \\
\hline $16-22$ & $256(25 \cdot 1)$ & $38(14.8)$ & $3.9(1.9$ to 7.8$)$ \\
\hline 23-29 & $318(31 \cdot 1)$ & $27(8 \cdot 5)$ & $2 \cdot 2(1.1$ to 4.6$)$ \\
\hline$\geqslant 30$ & $234(22.9)$ & $9(3.8)$ & 1.0 \\
\hline \multicolumn{4}{|l|}{ Oedema $(n-1106)$ : } \\
\hline Present & $320(28.9)$ & $102(31 \cdot 9)$ & $3.1(2.4$ to 4.0$)$ \\
\hline Absent & $786(71 \cdot 1)$ & $81(10 \cdot 3)$ & 1.0 \\
\hline \multicolumn{4}{|l|}{ Age (years) $(n=1100)$ : } \\
\hline$<1$ & $302(27 \cdot 5)$ & $53(17 \cdot 5)$ & $1.2(0.8$ to 1.8$)$ \\
\hline 1 to 22 & $197(17.9)$ & $28(14 \cdot 2)$ & $1.0(0.6$ to 1.5$)$ \\
\hline 2 to 5 & $325(29 \cdot 5)$ & $63(19 \cdot 4)$ & $1.3(0.9$ to 1.9$)$ \\
\hline$\geqslant 5$ & $276(25 \cdot 1)$ & $40(14.5)$ & 1.0 \\
\hline
\end{tabular}

months, 24 months to $<5$ years, and $\geqslant 5$ years) was also included in the multivariate analyses as a potential confounder. With the variables selected from the first logistic regression new models were built including the interactions between any two of the three variables (arm circumference, serum albumin, and oedema). Because of the small number of subjects in some cells the categories of serum albumin concentration and arm circumference had to be grouped together to include interactions in the model. The interactions were tested by subtracting the log likelihood statistics of the models with and without the interactions terms. In a further analysis, each interaction was eliminated with a backward procedure based on the Wald test. Odds ratios and their $95 \%$ confidence intervals were estimated from the final logistic model. ${ }^{1417}$ The coefficients of this logistic equation were used as weights to compute a prognostic index for each subject. Survival curves (Kaplan-Meier curves combined with Breslow test) were estimated in four groups of subjects classified according to their value of the prognostic index. To form the groups quarters of the distribution of the prognostic index were considered; since survival was similar in the two lowest quarters, representing low risk subjects, these two groups were combined into one group. The fourth quarter was divided in two groups: the first one contained $15 \%$ of the total distribution (from $76 \%$ to $90 \%$ ) and the second one the last $10 \%$ of the total distribution (from $91 \%$ to $100 \%$ ). The purpose of that subdivision was aimed at isolating patients at highest risk. Finally, validation of the resulting logistic model was performed by using the data from the children admitted during the years 1989 to 1991 .

\section{Results}

The distributions of the indicators of protein energy malnutrition illustrate the poor nutritional condition of the children admitted at Lwiro (table I). With early deaths taken into account, 197 subjects died in hospital, which gives a figure of $17 \cdot 4 \%$ or a death rate of two per 100 children months.

The cumulative mortality varied with respect to each indicator and was especially high among children admitted with serum albumin concentrations lower than $16 \mathrm{~g} / \mathrm{l}$, with arm circumference under $115 \mathrm{~mm}$, or subscapsular skinfold thickness under $4 \mathrm{~mm}$ (table I). The proportion of deaths in the four age groups (table I) did not differ significantly. The logistic regression model was constructed with all anthropometric variables and age. Age was associated with serum albumin concentration and arm circumference. In children aged $<1$ year we observed the highest mean serum albumin concentration and, not unexpectedly, the lowest proportion of children with serum albumin concentration $<16 \mathrm{~g} / 1$ (table II). Mean arm circumference increased significantly with age; arm circumference was $<115 \mathrm{~mm}$ in about a third of the children under 1 year (table II). Among the anthropometric variables introduced in the multivariate analysis arm circumference was the only one to have a significant effect on mortality. In the logistic regression model taking arm circumference, serum albumin concentration, oedema, and age into account (table III), however, serum albumin concentration seemed to have the strongest effect on mortality. Oedema also contributed significantly to the model but to a lesser degree than the two other nutritional markers considered. When the model included both serum albumin concentration and age, age became significant. Inclusion of age produced a moderate reduction of odds ratios for arm circumference and a slight increase of odds ratios for serum albumin concentration.

Stratified analysis indicated that the risk of death in 
TABLE II-Mean (SD) serum albumin concentrations and arm circumferences and numbers (percentages) with concentration $<16 \mathrm{~g} /$ and circumference $<115 \mathrm{~mm}$ by age group

\begin{tabular}{lcccccccc}
\hline & \multicolumn{3}{c}{ Serum albumin $(g / 1)$} & & \multicolumn{3}{c}{ Arm circumference (mm) } \\
\cline { 2 - 3 } \cline { 7 - 9 } Age (years) & No & Mean(SD) & $\begin{array}{c}\text { No (\%) } \\
<16\end{array}$ & & No & Mean(SD) & $\begin{array}{c}\text { No (\%) } \\
<115\end{array}$ \\
\hline$<1$ & 264 & $28(7)$ & $10(4)$ & & 276 & $122(19)$ & $86(31)$ \\
1 to $<2$ & 184 & $25(8)$ & $20(11)$ & & 184 & $128(16)$ & $31(17)$ \\
2 to $<5$ & 307 & $21(8)$ & $110(35)$ & & 318 & $132(15)$ & $40(12)$ \\
$\geqslant 5$ & 253 & $22(9)$ & $73(28)$ & & 253 & $148(26)$ & $18(7)$ \\
\hline
\end{tabular}

TABLE III-Logistic regression model including arm circumference, age, serum albumin concentration, and oedema (147 dead, 808 discharged)

\begin{tabular}{|c|c|c|}
\hline Variables & $\begin{array}{l}\text { Odds ratio } \\
(95 \% \text { confidence interval })\end{array}$ & p Value \\
\hline \multicolumn{3}{|c|}{ Serum albumin $(g / 1)$ : } \\
\hline$<16$ & 12.49 (5.06 to 30.82$)$ & $<0.001$ \\
\hline $16-22$ & $3.43(1.48$ to 7.91$)$ & $<0.001$ \\
\hline $23-29$ & $1.81(0.79$ to 4.12$)$ & $0 \cdot 159$ \\
\hline$\geqslant 30$ & 1.00 & \\
\hline \multicolumn{3}{|c|}{ Arm circumference $(\mathrm{mm})$ : } \\
\hline$<115$ & $4.76(2.76$ to 8.21$)$ & $<0.001$ \\
\hline $115-124$ & $2.51(1.40$ to 4.51$)$ & 0.002 \\
\hline $125-134$ & $1.25(0.69$ to 2.25$)$ & 0.466 \\
\hline$\geqslant 135$ & 1.00 & \\
\hline \multicolumn{3}{|l|}{ Oedema: } \\
\hline Presence & 2.83 (1.65 to 4.85$)$ & $<0.001$ \\
\hline Absence & 1.00 & \\
\hline \multicolumn{3}{|l|}{ Age (years): } \\
\hline$<1$ & $2.60(1.29$ to 5.26$)$ & 0.008 \\
\hline 1 to $<2$ & $1.33(0.66$ to 2.69$)$ & 0.428 \\
\hline 2 to $<5$ & $0.95(0.55$ to 1.64$)$ & 0.851 \\
\hline$\geqslant 5$ & 1.00 & \\
\hline
\end{tabular}

children with arm circumference $<115 \mathrm{~mm}$ relative to children with arm circumference $\geqslant 125 \mathrm{~mm}$ was lower when the serum albumin concentration was $<16 \mathrm{~g} / 1$ than when it was $\geqslant 23 \mathrm{~g} / \mathrm{l}$ and that the relative risk associated with arm circumference was lower in the presence of oedema. In the logistic model, however, none of the interactions between the analysed indicators was significant. A prognostic index was derived from the logistic model (table III); high values of this index were associated with lower values of arm circumference, serum albumin concentration, and age and with the presence of oedema.

The figure shows the important decrease in the survival rates when the values of the prognostic index are high. The difference between survival rates for the subjects with low values of the prognostic index versus those with the highest values reached $25 \%$ at one week from admission and $40 \%$ at two weeks.

\section{Discussion}

In Africa mortality in patients admitted to hospital in a state of severe protein energy malnutrition with or

TABLE IV-Logistic regression model including arm circumference, age, serum albumin, and oedema obtained in validation set (admissions from 1989 to 1991: 158 dead, 1238 discharged)

\begin{tabular}{|c|c|c|c|}
\hline Variables & No & $\begin{array}{l}\text { Odds ratio } \\
\text { ( } 95 \% \text { confidence interval) }\end{array}$ & $\mathrm{p}$ Value \\
\hline \multicolumn{4}{|c|}{ Serum albumin $(g / 1)$ : } \\
\hline$<16$ & 169 & $6.46(3.32$ to 12.57$)$ & $<0.001$ \\
\hline $16-22$ & 313 & $3.18(1.77$ to 5.71$)$ & $<0.001$ \\
\hline $23-29$ & 513 & $1.34(0.76$ to 2.37$)$ & 0.317 \\
\hline$\geqslant 30$ & 401 & 1.00 & \\
\hline \multicolumn{4}{|c|}{ Arm circumference $(\mathrm{mm})$ : } \\
\hline$<115$ & 208 & $3.03(1.84$ to 4.98$)$ & $<0.001$ \\
\hline $115-124$ & 229 & $1.94(1.16$ to 3.24$)$ & 0.011 \\
\hline $125-134$ & 354 & $1.36(0.83$ to 2.24$)$ & 0.219 \\
\hline$\geqslant 135$ & 605 & 1.00 & \\
\hline \multicolumn{4}{|l|}{ Oedema: } \\
\hline Presence & 297 & $1.91(1.20$ to 3.02$)$ & $<0.006$ \\
\hline Absence & 1099 & 1.00 & \\
\hline \multicolumn{4}{|l|}{ Age (years): } \\
\hline$<1$ & 464 & 2.47 (1.30 to 4.69$)$ & 0.006 \\
\hline 1 to $<2$ & 266 & $2.04(1.07$ to 3.89$)$ & 0.030 \\
\hline 2 to $<5$ & 420 & $1.30(0.71$ to 2.37$)$ & $0 \cdot 396$ \\
\hline$\geqslant 5$ & 246 & 1.00 & \\
\hline
\end{tabular}

without oedema ranges from $9 \%$ to $30 \% .^{1-3818}$ Several studies have clarified the association between anthropometric indicators and hospital mortality. ${ }^{146}$ In Kivu province cumulative mortality is twice as high for wasted and stunted children when compared with their counterparts. Weight, however, is a difficult variable to interpret in malnourished patients. It depends on total body water content, the proportion of which is said to be abnormally high in malnourished children ${ }^{19}$ or abnormally low in dehydrated children.

More recently Briend et al have shown the importance of measurements of the arm circumference to predict death among children admitted for diarrhoeal disease. ${ }^{7}$ The arm circumference is a good indicator of the muscle mass, ${ }^{20}$ and muscle mass may be a major determinant of survival in prolonged undernutrition. ${ }^{21}{ }^{22}$ In Kivu we found mortality in children with an arm circumference $<115 \mathrm{~mm}$ to be 3.7 times higher than in those with an arm circumference $\geqslant 135 \mathrm{~mm}$. These results confirm the importance of measuring the arm circumference in the prediction of risk of death in hospital, especially as this measurement is easy to perform. Nevertheless, the arm circumference can be influenced by the fat panniculus or the presence of oedema, ${ }^{23}$ two common conditions in children admitted to hospital in central Africa.

Though most quoted studies consider only anthropometric variables several investigations have analysed the presence or absence of oedema at the time of

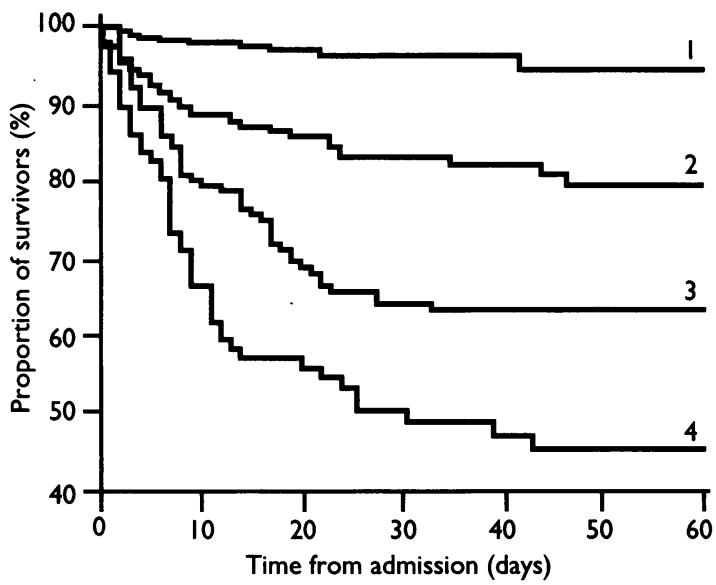

Survival curves during first 60 days of hospital admission (see text). Curve 1 ( $n=473)$ : low risk children, first two quarters (1-50\%) of prognostic index distribution. Curve $2 \quad(n=245)$ : medium risk children, third quarter (51-75\%) of prognostic index distribution. Curve $3(n=145)$ and curve $4(n=87)$ : fourth quarter $(76-100 \%)$ of prognostic index distribution, divided in larger group containing subjects from $76 \%$ to $90 \%$ (curve 3) of distribution and smaller group from $91 \%$ to $100 \%$ (curve 4), corresponding to upper tenth of distribution and referring to subjects at highest risk. Curves differ significantly $(p<0.001)$

admission. In Mexico a univariate analysis could not prove any significant association between the presence (or absence) of oedema and mortality among admitted patients. ${ }^{6}$ In Dakar, on the contrary, multivariate analysis disclosed a relative risk reaching $6 \cdot 2 .^{2}$ In Kivu the relative risk of mortality for children with oedema compared with those without is only about 3 .

The circulating concentration of transport proteins, traditionally albumin, has been used to define protein deficiency in clinical practice. ${ }^{24} 25$ This indicator of protein shortage is also associated with a higher risk of death in hospital; in children admitted to hospital with oedematous malnutrition the serum albumin concentration at admission was closely related to the mortality. ${ }^{8}$ Our findings suggest that in the Kivu region the same association that is valid for the oedematous children is also found among all the admitted children. Indeed, the highest relative risk recorded $(10 \cdot 6)$ corresponded to the group of children 
admitted with an albumin concentration $<16 \mathrm{~g} / \mathrm{l}$ as opposed to those admitted with an albumin concentration $\geqslant 30 \mathrm{~g} / \mathrm{l}$. Furthermore, as albumin concentration is independent of the variation in oedema its determination is already relevant on admission..$^{26}$ This variable, however, is not specific for protein deficiency as many other factors such as energy deficiency, zinc deficiency, infections, and liver disease are just as likely to be the cause of an observed low concentration of transport proteins as is protein deficiency. ${ }^{27}$

In healthy children serum albumin concentration does not vary much with age between 3 months and 5 years; in our data we observed on average higher serum albumin concentrations in very young children $(<1$ year) and lower concentrations in children between 2 and 5 years of age. This pattern can be explained by the characteristics of kwashiorkor itself, for which the peak incidence occurs at about 2 years, corresponding to weaning. ${ }^{28}$ Similar results have been found in Uganda. ${ }^{29}$ In Kivu in the multivariate analysis the serum albumin concentration seemed to have the dominant impact on mortality, although arm circumference and oedema remained important. This model has been verified on data collected from 1989 to 1991 ; all three indicators considered still had a significant effect on mortality (table IV), although the estimated odds ratios were lower than those observed in the present investigation (table III). This may result from the great variability in the characteristics of the admitted children and the various reasons for their admission. No significant interactions between serum albumin concentration, arm circumference, and oedema were detected in the logistic analysis.

We conclude from this work that in this relatively specific socioeconomic and nutritional environment of central Africa the recording of clinical symptoms such as oedema in hospital is not enough to detect reliably those children most likely to die, even though the symptom is significantly associated with hospital mortality. The measurements of the arm circumference, an indicator of the lean body mass, and the concentration of transport proteins such as the serum albumin seem to be crucial and complementary. It would be interesting to determine whether these criteria would be of the same relevance in outpatients living in the same region or among inpatients living in other regions.

This work was supported by a grant from the Fonds National de la Recherche Scientifique (number 3.4532.86). We also thank the Fondation Universitaire David et Alice Van Buuren.

1 Tolboom JJM, Ralitapole-Maruping AP, Kabir H, Molatsfli P, Anderson J. Severe protein energy malnutrition in Lesotho. Death and survival in hospital, clinical findings. Trop Geogr Med 1986;38:351-8.

2 Beau JP, Garenne M, Diop B, Briend A, Diop Mar I. Diarrhoea and nutritional status as risk factors of child mortality in a Dakar Hospital (Senegal). $\mathcal{F}$ Trop Pediatr 1987;33:4-9.

3 Van Roosmalen-Wiebenga MW, Kusin JA, De With C. Nutrition rehabilitation in hospital-a waste of time and money? Evaluation of nutrition rehabilitation in a rural district hospital in Southwest Tanzania. I Shortrehabilitation in a rural district hospital in

4 Sachdev HPS, Kumar Shiv, Singh KK, Satyanarayana L, Puri RK. Risk factors for fatal diarrhoea in hospitalised children in India. $f$ Pediatr Gastroenterol Nutr 1991;12:76-81.

5 Anon. Classification of infantile malnutrition. Lancet 1970;ii:302.

\section{Clinical implications}

- In developing countries protein energy malnutrition in children admitted to hospital contributes to a high case fatality rate

- Anthropometric measurements alone may not predict which children have a high risk of dying

- In this study death was more common among wasted children (stunted or not) and those with a mid-upper arm circumference smaller than $125 \mathrm{~mm}$, a serum albumin concentration lower than $16 \mathrm{~g} / \mathrm{l}$, and oedema

- Serum albumin concentration was the best single predictor of subsequent risk of dying

- In central Africa combined anthropometric measurements and biology with clinical symptom are useful predictors of death

- In central Africa both physical measurements and physiological variables need to be considered to detect which malnourished children are at risk of dying

6 Gomez F, Galvan RR, Frenk S, Cravioto Munoz J, Chavez R, Vasquez J. Mortality in second and third degree malnutrition. $\mathcal{F}$ Trop Pediatr 1956;2: 77-83.

7 Briend A, Dykewicz C, Graven K, Mazumder RN, Wojtyniak B, Bennish K. Usefulness of nutritional indices and classifications in predicting death of malnourished children. BMF 1986;293:373-5.

8 Hay RW, Whitehead RG, Spicer CC. Serum-albumin as a prognostic indicator in oedematous malnutrition. Lancet 1975;ii:427-9.

9 Waterlow JC. Classification and definition of protein-calorie malnutrition. BMF 1972;iii:566-9.

10 National Center for Health Statistics (NCHS). NCHS growth curves for children, birth-18 years, United States. Washington, DC: US Department of Health Education and Welfare, 1977. (Vital and health statistics. Series II, publication No (PHS) 78-1650.)

11 Sonnet J, Rodhain J. Etudes des protéines sérique par l'électrophorèse sur papier. I. Techniques et résultats normaux. Revue Belge de Pathologie 1952;22:226-40.

12 Marija J. Norusis. SPSS statistical data analysis. Chicago, Illinois: SPSS, 1990

13 Dixon WJ. BMDP statistical software. Berkeley: University of California Press, 1990.

14 Armitage P, Berry G. Statistical methods in medical research. 2nd ed. Oxford: Blackwell Scientific Publications, 1987:205-9.

15 Hosmer DW, Lemeshow S. Applied logistic regression. New York: John Wiley, 1989:25-173.

16 Kalbfleisch $\mathrm{JD}$, Prentice RL. The statistical analysis of failure time data. New York: John Wiley, 1980:12-9.

17 Kleinbaum DG, Kupper LL, Morgenstern H. Epidemiologic researchprinciples and quantitative methods. New York: Van Nostrand Rheinhold, 1982:103-23.

18 McFarlane H, Reddy S, Adcock KJ, Adeshina H, Cooke AR, Akene J. Immunity, transferrin and survival in kwashiorkor. BMf 1970;iv:268-70.

19 McLaren DS, Burman D. Textbook of paediatric nutrition. 2nd ed. Edinburgh: Churchill Livingstone, 1982.

20 Trowbridge FL, Hiner CD, Robertson AD. Arm muscle indicators and creatinine excretion in children. Am f Clin Nutr 1982;36:691-6.

21 Briend A, Garenne M, Maire B, Fontaine O, Dieng K. Nutritional status, age and survival: the muscle mass hypothesis. Eur f Clin Nutr 1989;43:715-26.

22 Briend A. Using anthropometry to identify children with a high risk of dying. Indian Pediatr 1988;25:930-8.

23 Jeliffe DB. Appréciation de l'état nutritionnel des populations. WHO Monogr 1966;53:194-8.

24 Waterlow JC. Protein energy malnutrition. London: Edward Arnold, 1992

25 Alleyne GAO, Hay RW, Picou DI, Stanfield JP, Whitehead RG. Protein energy malnutrition. London: Edward Arnold, 1977.

26 Golden MHN, Golden BE, Jackson AA. Albumin and nutritional oedema. Lancet 1980;i:114-6.

27 Golden MHN. Transport proteins as indices of protein status. Am $f$ Clin Nutr 1982;35:1159-65.

28 Hennart $\mathrm{Ph}$, Masse-Raimbault AM, Vis HL. The ongoing evaluation of protein-energy malnutrition. Children in the Tropics 1984;149-50:38-44.

29 Coward WA, Whitehead RG, Coward DG. Quantitative changes in serum protein fractions during the development of kwashiorkor and in recovery. Brf Nutr 1972;28:433-41.

(Accepted 2 fuly 1993) 